\title{
PIONEER
}

VOLUME 11, Issue 1, June 2019: 1 - 11

\section{THE ANALYSIS OF MARXISM IN THE MOVIE JACK THE GIANT SLAYER}

\author{
Badri Akandi \\ University of Abdurachman Saleh Situbondo \\ badri.akandi111@gmail.com \\ Dwi Taurina Mila \\ University of Abdurachman Saleh Situbondo \\ dwi.meela@gmail.com
}

\begin{abstract}
This research was about Marxism in Jack the Giant Slayer on social class and kind of Marxism. Marxism was an important thing in the society because Marxism wanted to remove social classes. Thus, this research was to describe how social classes could influence someone's roles in the society. This research used descriptive qualitative method. The research was conducted by accommodating two theories: kinds of Marxism by Tyson (2006) and social class by Barry (2002). Tyson's theory (2006) classifies Marxism into classism, patriotism, religion, rugged individualism, and consumerism. On the other hand, Barry's theory (2002) classifies social class into the upper class, the middle class, and the lower class. The findings of the analysis reveal that there were ten data in Jack the Giant Slayer. The researcher found ten forms of Marxism, There were one form of classism, twelve forms of rugged individualism, and one form of consumerism. The most of kind dominant Marxism was classism. Besides, the researcher found three forms of social class, they were the upper class, the middle class, and the lower class. There were four characters of the upper class, one character of the middle class, and two characters of the lower class. The dominant social class was the upper class, which appeared in four characters.
\end{abstract}

Keywords: marxism, social class, kind of marxism

\section{INTRODUCTION}

Marxism was an ideology created by Karl Marx. According to Milios, Dimoulis and Economakis (2002:03), Marx developed his economic theory, under the rubric of A Critique of Political Economy, mainly in the period 1857-1867. It was a well-defined system, structured as a logical array of original concepts and analyses based on Marx's notions of value and surplus-value. Marxian economics emerged from Marx's earlier historic-sociological analyses and was formulated along with a new methodological approach. The Marxist doctrine was omnipotent because it was true. It was comprehensive and harmonious, and provides men with an integral world outlook 
irreconcilable with any form of superstition, reaction, or defense of bourgeois oppression.

Marxism was an ideology arranged a big theory that included economic system, social system, and politic system. The followers of this theory were known as Marxist. Marxism consisted of dialectical materialism, historical materialism, and the application of this theory on social life. Marxism appeared as protest for Capitalism. Karl Mark (the creator of Marxism) deemed that Capitalism gave advantages for Capital group, but gave disadvantages for proletariat group.

Literature is the imitation of life. Through reading literary works, readers can learn about the condition of a society in a particular time. As De Bonald said in Wellek and Warren, "literature is an expression of society" (1956: 95). It means that literature reflects a situation or condition such as politics, economics, and social life of some people in some certain period of time. By reading literature, the readers may learn and then probably imitate the norms such as the way people dress, act or socialize in real life.

Movie was one of literary work in which Marxism phenomena could be found. According to Asmawati (2015), movie was a way to express a feeling and imagination of someone. Movie was like drama which both had an important part to express a feeling and imagination of someone. Movie also had the basic elements of a literary work those plot and characters. Movie consisted of series of moving pictures, usually showed in a cinema or on television and colored with a story. The statement described that movie was like real life, which it could create arrangement of moments life. Therefore, Marxism in the movie could happen like Marxism in real life.

Jack the Giant Slayer (previously titled Jack the Giant Killer) is a 2013 American fantasy adventure film based on the British fairy tales Jack the Giant Killer. The film is directed by Bryan Singer(Hoult:2014). The film tells about Jack, a young farmhand who must rescue a princess from a race of giants after inadvertently opening a gateway to their land in the sky. Jack has no royal blood. A farmer with a small cottage and Isabelle is the only daughter of the Cloister Kingdom long time ago, a king cast a giant up into the sky. In present day of the movie, a monk stole some beans of that tree. In his escape, he gave Jack to protect it and later captured by the king's army. Jack took those beans with him knowing nothing about it. Jack fall in love with the princess. They 
met on the market for the first time and jack saved Isabelle. When at night the princess run away from the palace and accidentally took shelter in a slum house. Jack there. There were lots of conversations between Jack and princess from a satirical conversation as if insulting Jack. Unfortunate event started. When one of Jack's beans fell and grew. The tree started to rise. It touched the sky with the cottage and the princess. King and Jack's warriors went up into the sky to save the princess who is carried by a tree into the sky and they meet with the giant assassins but Jack can save Princess Isabelle back home. Later the giants came down to destroy the kingdom and Jack saved them all wearing that legendary crown which will make him the next king.

There are some researches which are related with this research. The first research's done by Oktian (2015). His research concerned on class conflict that happen within society in time film. The researcher used Marxism as the basic theory which related to the class conflict. The researcher used qualitative descriptive analysis as the method to analyze the characteristics of both classes in the film that related to role of Sylvia Weis to do revolution and the class conflict that portrayed in the film.

The second research is Utomo (2013) with his research's title "Marxist Analysis of French Revolution in Charles Dickens' A Tale of Two Cities". He studied about the social situation in Paris and London during the French revolution. There is a conflict between the aristocrat and proletariat class. The intrinsic elements such as characters, conflicts, setting in the novel and the concepts of Marxism were applied in the discussion of this novel. This research is using Karl Mark's theory.

The last research is Yaris, (2017) with his research's title "Class Struggle in Capitalist Society in Ally Condie's Novel". This research tells about Marxism in capitalist society in Ally Condie's novel on class struggle in capitalist society. The researcher used Mark's Theory.

The differences of this research with the previous study are from the object and the source of the research. This research analyzed Marxism in Jack the Giant Slayer, while other previous researches were using different object of study. The first previous study was concerned on class conflict that happen within a society in the film while this research analyzed class conflict that happen within society in time film which has different analysis with this research that this research analized about social class in the movie Jack the Giant Slayer. The second research focused on Marxist Analysis of 
French Revolution in Charles Dickens' A Tale of Two Cities. His research tells about the social situation in Paris and London during the French revolution and the last research also tell about class struggel and captalist society in Ally Condie's Novel as the data which has different sourch with this research that uses movie as the object of study. From the previous studies above, the researcher will analyse social classes.

Marxism was an ideology that followed Karl Marx ideas in the mid-19 ${ }^{\text {th }}$ Century. Karl Heinrich Marx born on 5 May, 1818 in Trier, Russia and died on 14 March, 1883 in London, England. Marx arranged a big theory that relate to economic system, social system, and politic system (Kreis, 2000 in Rahmadini, 2016). The theory was known as Marxism.

According to Tyson (2006:54), from a Marxist perspective, differences in socioeconomic class divide people in ways that are much more significant than differences in religion, race, ethnicity, or gender.

According to Labriola (1895-1896), Marxism theory also explain about a system of economic, social, and political philosophy based on ideas that view social change in terms of economic factors. A central tenet is that the means of production is the economic base that influences or determines the political life. Under Marxism, outdated class structures were supposed to be overthrown with force (revolution) instead of being replaced through patient modification. It held that as capitalism has succeeded feudalism, it will be removed by a dictatorship of the workers (proletariat) called socialism, followed quickly and inevitably by a classless society which governs it without a governing class or structure.

\section{Types of Marxism}

According to Tyson (2006:59), there are five types of Marxism, they are classism, patriotism, religion, rugged individualism, and consumerism.

\section{Classism}

Classism was an ideology that equates one's value as a human being with the social class to which one belongs: the higher one's social class, the better one was assumed to be because quality was "in the blood," that was, inborn. From a classist perspective, people at the top of the social scale were naturally superior to those below them: those at the top were more intelligent, more responsible, more trustworthy, more 
ethical, and so on. People at the bottom of the social scale, it followed, were naturally shiftless, lazy, and irresponsible. Therefore, it was only right and natural that those from the highest social class should hold all the positions of power and leadership because they were naturally suited to such roles and the only ones who could be trusted to perform them properly.

\section{Patriotism}

Patriotism was an ideology that keeps poor people fighting wars against poor people from other countries (one way or another, sufficient money could generally kept one out of the armed forces during war time or, at least, out of the combat units) while the rich on both sides rake in the profits of war time economy. Because patriotism led the poor to see themselves as members of a nation, separated from other nations, rather than as members of a worldwide oppressed class opposed to all privileged classes including those from their own country, it prevented the poor from banding together to improve their condition globally.

\section{Religion}

Religion was an ideology that helped to keep the faithful poor satisfied with their lot in life, or at least tolerant of it, much as a tranquilizer might did. Karl Mark called it as "the opiate of the masses". The question of God's existence was not the fundamental issue for Marxist analysis; rather, what human beings do in God's name organized religion was the focus. For example, while many Christian religious groups work to feed, clothe, house, and even educate the world's poor, the religious tenets that were disseminated along with the food and clothing included the conviction that the poor, if they remained nonviolent, would find their reward in heaven. Obviously, the 10 percent (or less) of the world's population who own 90 percent (or more) of the world's wealth had a vested interest in promoting this aspect of Christian belief among the poor and historically had exploited Christianity for just this purpose. Indeed, the Bible had been used successfully to justify and promote the enslavement of Africans in America and the subordination of women and non-straight people.

\section{Rugged individualism}

Rugged individualism was an ideology that romanticized the individual who strike out alone in pursuit of a goal not easily achieved, a goal that often-involved risk and one that most people would not readily undertake. Rugged individualism was a 
cornerstone of the American dream. In the past, such a goal would have been, for example, the rush for gold and silver on the American frontier, an attempt in which many individuals risked losing their lives. Today, such a goal might be the undertaking of a high-risk business, in which one risks losing all one's money. Although it may sound like an admirable character trait, Marxist thinkers considered rugged individualism an oppressive ideology because it put self-interest above the needs and even above the survival of other people. By keeping the focus on "me" instead of on "us," rugged individualism worked against the well-being of society as a whole and of underprivileged people in particular. Rugged individualism also gave us the illusion that we made our own decisions without being significantly influenced by ideology of any sort when, in fact, we were all influenced by various ideologies all the time, whether we realized it or not.

\section{Consumerism}

Consumerism was an ideology that said "I'm only as good as what I buy." Thus, it simultaneously fulfills two ideological purposes: it gave me the illusion that I could be "as good as" the wealthy if I could purchase what they purchased or a reasonable facsimile thereof (albeit on credit) and it filled the coffers of the wealthy who manufactured and sold the consumer products I buy and who reap the 15-20 percent interest on my credit card bills. Consumerism could be meant as shopped until you dropped.

\section{Social Class}

According to Barry $(2002: 157)$, social class in the society is divided into three classes, those are lower class, middle class, and upper class.

\section{Lower class}

The first type of social class was lower class. This class was characterized by poverty. The lower classes were usually laborers and peasant. The peasant lived in the rural areas, they worked in the farm, while the labors lived in urban areas, and they worked for the factories. They survived in some societies from the welfare of the states, they were called social spillover, employed people may become extremely poor, they lack of the basic and most of them were illiterate. However, a poor person could be trained, for example someone who gave the peanut seed and a farmer. 


\section{Middle class}

The second type of social class was middle class. This class was characterized as the sandwich in the society. The middle class consequently, had more money than lower class, and they are usually a doctor, an engineer, an architect, a lawyer and a manager. However, they had less money than upper class. This class had two types of people, the first class was less educated, which was classified by their lower incomes, they had their own business, they created employment, but this class was also hard workers. They worked in order to survive because they were proprietors of a little company. The feature of this class was that they possess any property. The second class was among the lower class and the upper class. They may do a national subversion against the economic system imposed by the bourgeoisie. Some people in the middle class that was successful members of the middle class would become members of the bourgeoisies or upper class.

\section{Upper class}

The last type of social class was upper class. This class had two kind of group, which are distributes in: lower upper and upper. The first group had less prestige, because they did their money with investment on new business, which became the new riches of the society. The second group was more prestigious, because their wealth was from long time ago. This class was extremely wealthy, because they had accumulated the capital of their family. The upper class was generally contained within the wealthiest of the population. Currently, the magnates of the upper class were partners of multinational and transnational corporations.

\section{METHODOLOGY}

This researcher used descriptive qualitative research design that described and explained data qualitatively. The data source was a movie entitled Jack the Giant Slayer. In this research, the data are in the form of dialogue, appearance and the behaviors of the character in the movie Jack the Giant Slayer. The research instrument was the researcher himself. The researcher was the key instrument. The researcher's attendance was so important because the researcher acted as the collector of the data, analyses and report's maker of the research.

The data were collected using document analysis. There were some steps of collecting the data in order to complete this research: (1) Watching the movie Jack the 
Giant the Slayer movie; (2) Looking for the phenomenon that showed Marxism in Jack the Giant Slayer; (3) Finding the sentences of the dialogue, appearance and the gesture in the movie; (4) Classifying the Marxism from its types and social classes.

There were some stages done to analyze the data. According to Miles and Huberman (1984), there were three steps to analyze the data such as data reduction, data display, and conclusion drawing or verification. The researcher adapted data reduction into technique of data collection and just put two items to analyze the data, they were data display and data analysis. Data display: The researcher classified the scenes based on the data after the researcher analyzed Marxism in Jack the Giant Slayer. Data Analysis: To analyze the data, the researcher used two theories. The researcher used Tyson's theory (2006) to analyze types of Marxism, and Barry's theory (2002) to analyze social class in the society.

\section{FINDINGS AND DISCUSSION}

\section{Finding}

The researcher analyzed social class and kinds of Marxism in Jack the Giant Slayer. The researcher found ten data in the movie. From the data, the researcher found kinds of Marxism and social class. When analyzing the kinds of Marxism, the researcher found four kinds of Marxism from five forms of the kind of Marxism (proposed by Tyson (2006)). These four forms are divided into ten forms, one form of rugged individualism, five forms of classism and one form of consumerism, and three forms of patriotism. For social class, the researcher found seven characters, four characters of upper class, one character of middle class, and two characters of lower class.

The researcher found three forms of social classes, they were the upper class, the middle class, and the lower class. In this movie, there were four characters who belonged to upper class, they were King Brahmwell, Princess Isabelle, Lord Elmont and Lord Loderick. King Brahmwell who belonged to upper class was found in data number 6 and 9. Princess Isabelle who belonged to upper class was found in data number 4 and 5. Lord Elmont who belonged to upper class was found in number 2, 3, and 7. The last, Lord Roderick who belonged to upper class was found in datum 8 . 


\section{DISCUSSION}

Based on the result of data analysis, the researcher found the dominant kinds of Marxism and social class in the movie. In this research, the dominant kind of Marxism found was classism, and the dominant social class was the upper class. Classism became the dominant kind of Marxism because the frequent of it on the utterance was high and according to Tyson (2006) classism is an ideology that believes upper class is more clever, respected, and responsible than the lower class because in this movie always happens cases in which the upper class had got to be respected by the lower class. There were five forms of classism. The upper class became dominant class in the movie because the people from the upper class were found most frequent in the utterances. According to Barry (2002), This class was extremely wealthy, because they had accumulated the capital of their family. The upper class was generally contained within the wealthiest of the population. There were four people who belonged to upper class, they were King Brahmwell and Princess Isabelle who were from noble blood, whereas Lord Elmont and Lord Roderick were rich because of their high position. Thus, they belong to upper class meanwhile, patriotism and rugged individualism, consumerism are the less dominant types of Marxism in the movie. Besides, the low dominant social classes in the movie were the middle class and the lower class. The relation between social class with type of Marxism is in this movie the upper class is more dominant in which upper class assumes classism is an ideology that was believed as the better quality than lower class.

After the researcher found the result of data analysis, the researcher compared the result with the results of previous researches. They were Oktian's research, Utomo's research and Yaris's research. There were differences between those researches to the result of previous researches. The first was Oktian's research (2015). His research concerned class conflict that happen within society in time film. As the result, the writer's first finding is the distinction of characteristic between bourgeoisie and proletarian in the film. The second was Utomo's research. The result of the research showed that background of French revolution was economic problem which caused discrepancy between aristocrat and farmers. Then, the last was Yaris' research (2017). The research told about Marxism in Capitalist Society in Ally Condie's Novel on class

struggle in capitalist society. It showed the social condition in capitalist society like 
class distinction and human exploitation. However, the result of this research showed that classism is the most dominant type of Marxism and upper class is the most dominant social class in Jack the Giant Slayer.

The relation among those previous researches with my research was Marxism bring negative effects toward lower class. Actually, life without different social class is better, and it will create a peaceful condition. There is also a thin line between the result of this research which with the result of the previous research. Upper class people always show characteristic that they are the most respectful and the smartest one. Therefore, they have the lower classes under their power or control.

\section{CONCLUSION AND SUGGESTION}

This movie wants to show that social class existed in the society. The dominant social class is upper class. People who belong to upper class mostly believed that they were more respected. They also had power to handle the classes under. Finally, life without different social class is better. However, maximal efforts are needed to remove social classes. Therefore, we need to try hard to omit social class, to make life better and balanced.

Based on the data found in this research, the researcher suggested that the research can be an additional reference in Marxism analysis. It is also recommended for the next researchers to use Barry's theory (2002) to analyze social classes and Tyson's theory (2006) to analyze kinds of Marxism to conduct researches on other areas.

\section{REFERENCES}

Asmawati, N (2015). "Maleficent's Character Development as Seen in Maleficent Movie (Unpublished Thesis)". Yogyakarta: Islamic University Sunan Kalijaga,.

Barry, P (2002). Beginning Theory: An Introduction to Literary and Cultural Theory $\left(2^{\text {nd }} e d\right)$. Wales: University Press

Creswell, J.W. (1998). Qualitative Inquiry and Research Design: Choosing among Five Approaches. California: Sage Sublication Inc

Hoult N. (2014). Review Summary of Jack the Giant Slayer.http://allreadersHoult.com/movie-review-summary/Jack-the-giantslayer-36752 
Labriola A, 1.-1. (1975). "Marxian economics, Marxism, Historical Materialism, Positivism, Idealism, Croceanism, Jacobitism, Social Movements". Journal of the History of Ideas. 22.

Milios, J., Dimoulis, D., \& Economakis, G, (2002). Karl Marx and the Classics: An Essay on Value, Crises and the Capitalist Mode of Production. Burlington: Ashgate

Miles, M. B. \& Huberman, A. M, (1984). Qualitative Data Analysis: A Source Book of New Methods. California: SAGE Pablications. Inc.

Oktian Y. (2015). "Class Conflict that Happen within Society in Time Film". (Unpublished Thesis). Jakarta: Syarif Hidayatullah State Islamic University.

Rahmadini, A (2016, 15 June). Pemikiran Politik Karl Marx. http://anggia-rahmadinifisip14.web.unair.ac.id/artikel_detail-161483-Pemikiran-Politik Barat$\underline{\text { Pemikiran Politik Karl Marx.html }}$

Tyson, L (2006). Critical Theory Today (2 ${ }^{\text {nd }} e d$.).New York: Routledge

Utomo, Y.C.U (2013). "Marxist Analysis of French Revolution in Charles Dickens' A Tale of Two Cities". (Unpublished Thesis). Semarang: Diponegoro University.

Wellek, R and Warren, H (1956). Theory of Literature, Brace and Compani. 22. New York - Printed in the States of America.

Yaris, A. A. (2014). "Class Struggle in Capitalist Society in Ally Condie's Novel Crossed". Thesis, 21 